\title{
Record of morphological deformities in Corydoras aff. longipinnis in two reservoirs under urban influence in Upper Iguaçu and Southern Coastal basins in Paraná State, Brazil
}

\author{
Fábio Teruo Mise ${ }^{1,2 *}$, Luiz Tencatt ${ }^{3} \&$ Bruno Ferreira dos Santos ${ }^{4}$ \\ ${ }^{1}$ Departamento de Biologia, Universidade de São Paulo, São Paulo, SP, Brazil \\ ${ }^{2}$ Faculdade de Filosofia Ciências e Letras de Ribeirão Preto, Universidade de São Paulo, Ribeirão Preto, SP, Brazil \\ ${ }^{3}$ Universidade Estadual de Maringa, Maringá, PR, Brazil \\ ${ }^{4}$ Universidade Federal de Mato Grosso do Sul, Campo Grande, MS, Brazil \\ *Corresponding author: Fábio Teruo Mise, e-mail:fabio.mise@usp.br
}

MISE, F. T., TENCATT. L., SANTOS, B. F. Record of morphological deformities in Corydoras aff. longipinnis in two reservoirs under urban influence in Upper Iguaçu and Southern Coastal basins in Paraná State, Brazil. Biota Neotropica. 17(1): e20160230. http://dx.doi.org/10.1590/1676-0611-BN-2016-0230

\begin{abstract}
In this work we report on the presence of morphological deformities in Corydoras aff. longipinnis from two reservoirs in Paraná State, Brazil. The frequency of deformities in the fish populations was $11 \%$ in Iraí and $10.5 \%$ in Capivari reservoirs. Considering that the frequency may be associated with impacts caused by anthropic activities, this information can be used as a metric in management systems and environmental monitoring.
\end{abstract}

Keywords: Anthropization, Corydoradinae, Malformations, Neotropical region, Urban reservoirs.

\section{Registro de anomalias morfológicas em Corydoras aff. longipinnis em dois reservatórios sob influência urbana no Paraná, Brasil}

\begin{abstract}
Resumo: Neste trabalho relatamos a presença de deformidades morfológicas em Corydoras aff. longipinnis de dois reservatórios no estado do Paraná, Brasil. A frequência das deformidades observadas nas populações analisadas foi de $11 \%$ no reservatório de Iraí e 10,5\% no reservatório de Capivari. Considerando que a frequência pode ser associada a impactos causados por atividades antrópicas, essa informação pode ser usada como uma métrica em sistemas de gestão e monitoramento ambiental.
\end{abstract}

Palavras-chave: Antropização, Corydoradinae, Malformações, região Neotropical, Reservatórios Urbanos.

\section{Introduction}

Deformities in aquatic organisms are widely used as an environmental indicator, and their presence are related to several anthropic impacts (Sanders et al. 1999, Sun et al. 2009, Flores-Lopes \& Reuss-Strenzel 2011). These deformities can originate from a direct interference in the organisms development caused by chemical compounds (such as heavy metals), or can be result of environmental changes due to anthropic activities that decreases population size favoring endogamy (Reash \& Berra 1989; Sánchez et al. 2011, Messaoudi et al. 2009). In addition, environmental changes can make populations susceptible to parasites, cause parasite populations to increase, or cause intermediate host populations to increase. The resulting increase in parasitic infestation can cause diseases which in turn result in morphological deformities (Cunningham et al. 2005, Johnson et al. 2007).

Morphological deformities registered in Neotropical fish comprise dysplasia (atrophy, hypertrophy, torsion, deformation) on opercular bones, maxilla-mandibular apparatus, branchiostegal bones, fins and eyes. Also, tumors (neoplasias) on bones and skin and deformations on vertebral column (kyphosis, lordosis and scoliosis) can be observed (Flores-Lopes \& Reuss-Strenzel, 2011). The occurrence of these morphological conditions coupled with other metrics, such as proportion of taxonomic groups, quantity of tolerant species, trophic position of species, fluctuating asymmetry, and the fish health, are present in many environmental assessments (Jaramillo-Villa \& Caramaschi, 2008; Flores-Lopes et al. 2010).

The present work sought to register, identify, illustrate and quantify the morphological abnormalities in Corydoras aff. longipinnis from two reservoirs under urban influence. Since the occurrence of deformities in this species have been registered in polluted waters (Malabarba et al. 2004; Flores-Lopes \& Reus-Strenzel 2011), the importance of this kind of evaluation in environmental assessments can be highlighted considering that poor environmental conditions can be related to occurrence of deformities.

\section{Material and Methods}

The two studied reservoirs are Iraí and Capivari, respectively located in the upper Iguaçu and Southern Coastal river basins, Paraná State, Brazil. The Iraí reservoir is located in the metropolitan area of Curitiba (25'24'33"S 49 6' 16") and is used for water supply (Rodrigues et al., 2005). The Capivari is located $50 \mathrm{~km}$ from Curitiba $\left(25^{\circ} 10^{\prime} 46^{\prime \prime} \mathrm{S} 48^{\circ} 52^{\prime} 51\right.$ '” $)$ 
and its water is used by a hydroelectric plant (Parigot de Souza power plant) (Rodrigues et al., 2005). Both reservoirs are located in the Atlantic forest biome, presenting fragments of semideciduous ombrophilous forest, and araucaria forest (Maack, 2012).

The fish were collected in 2002, using cast nets and trawl nets, fixed in formaldehyde $10 \%$ and conserved in alcohol $70^{\circ} \mathrm{GL}$. Species identification followed Tencatt et al. (2016). Each individual was examined using a visual method to identify morphological abnormalities, following Flores-Lopes \& Reuss-Strenzel (2011). The frequency of deformities was calculated based on the number of abnormality occurrences relative to the total number of individuals. The use of the number of occurrences instead of the number of individuals with abnormalities was adopted because some individuals presented more than one abnormality.

Examined specimens of Corydoras aff. longipinnis are hosted in the Coleção Ictiológica do Núcleo de Pesquisas em Limnologia, Ictiologia e Aquicultura (NUP) - Universidade Estadual de Maringá. Collection codes of the examined material are: 17742 (55), from Capivari reservoir; and 17738 (48); 17739 (6); 17740 (2) 17741 (42); 17743 (29); 17744 (7); 17745 (3); 17746 (153); 17747 (35), from Iraí reservoir (numbers in parentheses indicate the quantity of analyzed specimens).

\section{Results and Discussion}

A total of 380 individuals were analyzed, 325 from Iraí and 55 from Capivari reservoirs. When considering both reservoirs, an $11 \%$ frequency of deformities was detected. The deformities detected were dysplasia in the fins $(7.10 \%$ frequency), dysplasia in the maxilla and jaws $(0.26 \%)$, dysplasia in the branchiostegal bones $(0.53 \%)$, dysplasia in the bone plates
$(0.53 \%)$, deformations in the vertebral column $(0.26 \%)$, neoplasias $(0.53 \%)$ and other dysplasias (lumps and hollows, 2.10\%) (Figure 1 and Figure 2). These results are summarized in Table 1.

As previously discussed, most morphological deformities are related to negative anthropogenic influences on the environment (Sanders et al. 1999). An evaluation of water quality in the studied reservoirs, assessed from 2005 to 2008 classified Iraí as critically degraded (or polluted) and Capivari as moderately degraded (Instituto Ambiental do Paraná, 2009). In the same document, sewage discharges and industrial activities were also recorded from tributaries, resulting in an increase of nutrient concentrations in Capivari reservoir and consequently a decline in water quality.

More accurate analysis could elucidate which factors are responsible for the morphological deformities reported. Considering the industrial activities and sewage discharges, the presence of heavy metals and other kinds of pollutants, such as pesticides can be designated as potential causes of the deformities that were found.

Comparisons between populations found in conserved locations and those collected from polluted locals, can contribute to verify the natural frequency of occurrence of deformities in fish populations. Messaoudi et al. (2009) verified that polluted locals presented a frequency of deformities three times greater in relation to unpolluted areas. However, this comparison was made in marine environment, using other species. In Neotropical region, C. aff. longipinnis from the Guaíba lake, which is under urban influence, Flores-Lopes \& Reuss-Strenzel (2011) registered 43 and 81 occurrences of deformities in 3270 and 2601 individuals, respectively; clearly contrasting to the 49 occurrences in 705 individuals observed herein. Despite the lower number of examined specimens, the frequency observed herein

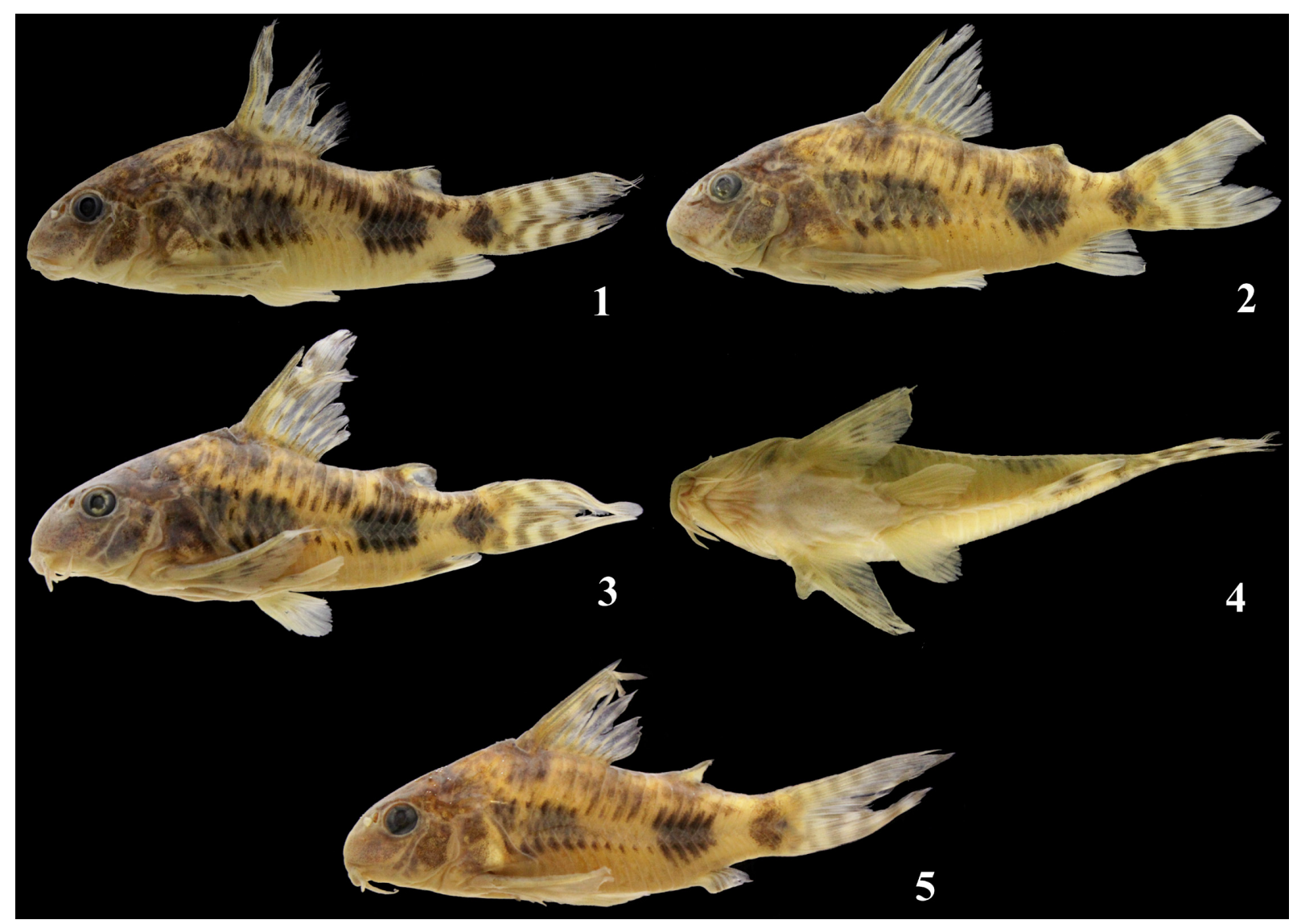

Figure 1. Fins and spines deformities in Corydoras aff. longipinnis: (1) dorsal spine dysplasia; (2) adipose fin dysplasia; (3) pectoral spine dysplasia; (4) pectoral spine neoplasia; (5) anal-fin rays dysplasia. 


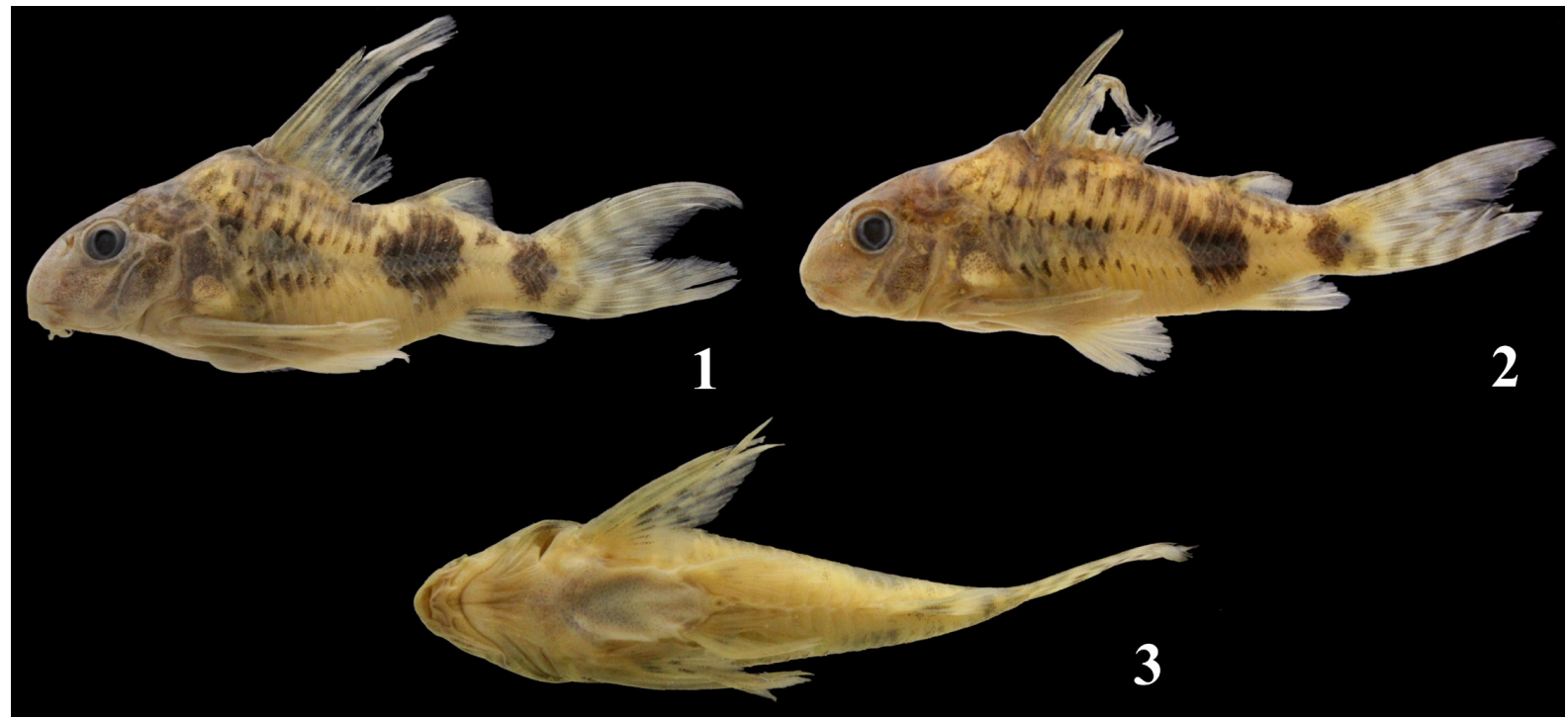

Figure 2. Bones dysplasia in Corydoras aff. longipinnis: (1) vertebral column; (2) head with hollow; (3) branchiostegal bones.

Table 1. Number of occurrences and frequency of deformities in Corydoras aff. longipinnis sampled in the Iraí and Capivari reservoirs.

\begin{tabular}{|c|c|c|c|c|c|c|}
\hline & \multicolumn{2}{|c|}{ Iraí reservoir } & \multicolumn{2}{|c|}{ Capivari reservoir } & \multicolumn{2}{|c|}{ Total } \\
\hline & Occurrence & Frequency & Occurrence & Frequency & Occurrence & Frequency \\
\hline Dysplasia in fins and spines & 24 & $7.38 \%$ & 3 & $5.45 \%$ & 27 & $7.10 \%$ \\
\hline Dysplasia in maxilla and jaws & 1 & $0.31 \%$ & 0 & $0 \%$ & 1 & $0.26 \%$ \\
\hline Dysplasia on branchiostegal bones & 1 & $0.31 \%$ & 1 & $1.81 \%$ & 2 & $0.53 \%$ \\
\hline Dysplasia on bone plates & 2 & $0.61 \%$ & 0 & $0 \%$ & 2 & $0.53 \%$ \\
\hline Neoplasias & 2 & $0.61 \%$ & 0 & $0 \%$ & 2 & $0.53 \%$ \\
\hline Column deformities & 1 & $0.31 \%$ & 0 & $0 \%$ & 1 & $0.26 \%$ \\
\hline Othes dysplasias & 6 & $1.85 \%$ & 2 & $3.63 \%$ & 8 & $2.10 \%$ \\
\hline Total & 37 & $11.21 \%$ & 6 & $10.53 \%$ & 43 & $11.31 \%$ \\
\hline
\end{tabular}

$(\approx 6.9 \%)$ is at least two times proportionally higher than in the Guaíba Lake $(\approx 1.3-3.1 \%)$.

The use of Iraí and Capivari reservoirs for human activities, such as water supply, energy generation, fishing, and recreation, emphasizes the importance of conducting proper environmental monitoring in these water bodies, since deformities in fish could indicate low water quality and presence of harmful substances. These statements highlight the use of fish as a potential biological indicator, but there is a need for more detailed analysis concerning the specific cause of deformities. Encouraging further survey efforts is essential to improve the monitoring and assessment of aquatic environments.

\section{Acknowledgements}

FTM and LFCT are grateful to the Programa de Pós-Graduação em Biologia Comparada - Faculdade de Filosofia Ciências e Letras de Ribeirão Preto and to the Programa de Pós-Graduação em Ecologia de Ambientes Aquáticos Continentais (PEA) - UEM, respectively, for providing conditions to realize this work. The Núcleo de Pesquisas em Limnologia, Ictiologia e Aquicultura (Nupélia) of the Universidade Estadual de Maringá and the Laboratório de Zoologia da Universidade Federal de Mato Grosso do Sul provided logistical support. The authors are also grateful to Andréa Bialetzki for providing the collecting data of the analysed speciens, to Celso Ikedo for taking the photos used in figures 1 and 2, and to Robert McLure and Steven Grant for kindly reviewing the English language of this manuscript. The authors also thank FAPESP and CNPq (process \#141061/2014-6) for financial support.

\section{References}

CUNNINGHAM, M. E., MARKLE, D. F., WATRAL, V. G., KENT, M. L. \& CURTIS, L. R. 2005. Patterns of fish deformities and their association with trematode cysts in the Willamette River, Oregon. Environ. Biol. of Fishes, 73: 9-19.

FLORES-LOPES, F.,CETRA, M. \& MALABARBA, L. R., 2010. Utilização de índices ecológicos em assembleias de peixes como instrumento de avaliação da degradação ambiental em programas de monitoramento. Biota Neotropica, 10(4): 183-193.

FLORES-LOPES, F. \& REUSS-STRENZEL, G.M. 2011. Frequency of morphological alterations in the fish of Lake Guaíba and its application to environmental monitoring. Bioikos 25:11-23.

INSTITUTO AMBIENTAL DO PARANÁ. 2009. Monitoramento da qualidade das águas dos reservatórios do Estado do Paraná no período de 2005 a 2008. Secretaria de Estado do Meio Ambiente e Recursos Hídricos. http://www.iap.pr.gov.br/arquivos/ File/boletins/RELATORIO_AGUA/relatorio_RESERVATORIOS_2005_2008. pdf (last access on 26/09/2016)

JARAMILLO-VILLA, U. \& CARAMASCHI, E. P. 2008. Índices de integridade biótica usando peixes de água doce: uso nas regiões tropical e subtropical. Oecol. Bras. 12: 442-462.

JOHNSON, P. T. J., CHASE, J. M., DOSCH, K. L., HARTSON, R. B., GROSS, J. A., LARSON, D. J., SUTHERLAND, D. R. \& CARPENTER, S. R. 2007. Aquatic eutrophication promotes pathogenic infection in amphibians. Proc. Natl. Acad. Sci. U.S.A. 104,15781-15786. 
MAACK, R. 2012. Geografia física do estado do Paraná, $4{ }^{\text {a }}$ edição. Curitiba, Imprensa Oficial do Paraná. 438p.

MALABARBA, L.R., PEREIRA, E.H.L., SILVA, J.F.P., BRUSCHL, J.R.W. \& FLORES-LOPES, F. 2004. Avaliação da qualidade da água através da frequência de anomalias morfológicas em peixes: estudo de caso do lago Guaíba, Rio Grande do Sul Brasil. Iheringia, Sér. Zool. 17:97-128.

MESSAOUDI, I., DELI, T., KESSABI, K., BARHOUMI, S., KERKENI, A. \& SAÏD, K. 2009. Association of spinal deformities with heavy metal bioaccumulation in natural populations of grass goby, Zosterisessor ophiocephalus Pallas, 1811 from the Gulf of Gabès (Tunisia), Environ. Monit. Assess., 156: 511:560.

REASH, R.B. \& BERRA, T.M. 1989. Incidence off in erosion and anomalous fishes in a polluted stream and a nearby clean stream. Water Air Soil Pollut. 47:47-63.

RODRIGUES. L., THOMAZ, S.M., AGOSTINHO, A.A. \& GOMES, L.C. 2005. Biocenoses em reservatórios: Padrões espaciais e temporais. Rima, São Carlos, p. 333.

SANDERS, R.E., MILTNER, R.J., YODER, C.O. \& RANKIN, E.T. 1999. The use of external deformities, erosion lesions and tumors (DELT anomalies) in fish assemblages for characterizing aquatic resources: a case study of seven Ohio streams. In Assessing the sustainability and biological integrity of water resources using fish communities (T.P. Simon, Ed.). CRC press, Boca Raton, p. 225-248.

SUN, P. L., HAWKINS, W. F., OVERSTREET, R. M. \& BROWN-PETERSON, N J. 2009. Morphological deformities as biomarkers in fish from contaminated rivers in Taiwan. Int. J. Environ. Res. Public Health, 6: 2307-2331.

TENCATT, L.F.C., BRITTO, M.R., PAVANELLI, C.S. 2016. Revisionary study of the armored catfish Corydoras paleatus (Jenyns, 1842) (Siluriformes: Callichthyidae), over 180 years after its discovery by Darwin, with description of a new species. Neotrop. Ichthyol. 14:75-94.

Received: 21/07/2016

Revised: 11/01/2017

Accepted: 12/01/2017

Published online: 20/02/2017 